\title{
Pendampingan usaha rumah tangga produk lokal khas Aceh asam belimbing (Averrhoa bilimbi Linn) Sunti untuk meningkatkan mutu dan harga jualnya
}

\author{
Dewi Yunita $^{1 *}$, Nurlaila², Yanti Meldasari Lubis ${ }^{3}$, Irfan $^{4}$ \\ ${ }^{1}$ Universitas Syiah Kuala, Banda Aceh, Indonesia, email: dewi_yunita@unsyiah.ac.id \\ 2Universitas Syiah Kuala, Banda Aceh, Indonesia, email: nurlaila99@mhs.unsyiah.ac.id \\ ${ }^{3}$ Universitas Syiah Kuala, Banda Aceh, Indonesia, email: yantimeldasari@unsyiah.ac.id \\ ${ }^{4}$ Universitas Syiah Kuala, Banda Aceh, Indonesia, email: irfan@unsyiah.ac.id \\ ${ }^{*}$ Koresponden penulis
}

\section{Info Artikel}

Diajukan: 2021-07-11

Diterima: 2021-11-28

Diterbitkan: 2021-12-19

Keywords:

Averrhoa bilimbi Linn; asam sunti; standing pouch

packaging

Kata Kunci:

belimbing wuluh; asam sunti; standing pouch packaging
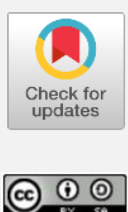

Lisensi: cc-by-sa

Copyright @ 2022 Dewi Yunita, Nurlaila, Yanti Meldasari Lubis, Irfan

\begin{abstract}
Asam sunti is a typical Acehnese spice made from salted, fermented and dried Averrhoa bilimbi Linn so that can be stored for 1-1.5 years. However, the process of asam sunti varies depending on the habits of the local community or consumer demand. This causes the product quality varies greatly and do not meet the quality standards. In this Community Service (PkM) activity, direct assistance to a household business in Alue Jeureujak Village, Babahrot Sub-District, Southwest Aceh District, Aceh Province. The aim of this PkM was to improve the manufacturing and packaging processes so that the quality of the products is improved and the selling price is increased. The PkM activity which lasted for 3 months with direct assistance at the location for 1 month consisted of several activities (visiting a production house, improving the asam sunti manufacturing process and packaging as well as calculating the selling price of asam sunti). Previously, the packaging only used plastic bags without labels, now the asam sunti has been sold in a labeled standing pouch packaging. After one month of mentoring, operating income increased from $R p 334.000$,- to $R p$ 436.000 ,- with sales scale from previously immeasurable to 80 packs of $250 \mathrm{gr}$ in one month.
\end{abstract}

\section{Abstrak}

Asam sunti merupakan bumbu masakan khas Aceh terbuat dari belimbing wuluh yang diasinkan, difermentasi dan dikeringkan sehingga dapat disimpan dalam jangka waktu 1-1,5 tahun. Namun, proses yang digunakan untuk mengolah belimbing wuluh segar menjadi asam sunti berbeda-beda, tergantung pada kebiasaan masyarakat setempat atau permintaan konsumen. Hal ini menyebabkan kualitas produk sangat bervariasi dan tidak memenuhi standar mutu. Pada kegiatan Pengabdian kepada Masyarakat (PKM), pendampingan langsung terhadap satu usaha rumah tangga di Desa Alue Jeureujak, Kecamatan, Babahrot, Kabupaten Aceh Barat Daya, Provinsi Aceh. Tujuan dilakukannya PkM ini adalah untuk memperbaiki proses pembuatan dan kemasan sehingga mutu produk yang dihasilkan tetap terjaga dan harga jual dapat ditingkatkan. Kegiatan PkM yang berlangsung selama 3 bulan dengan pendampingan secara langsung di lokasi selama 1 bulan terdiri dari beberapa kegiatan yaitu: peninjauan rumah produksi, perbaikan proses pembuatan asam sunti, perbaikan kemasan produk asam sunti, dan perhitungan harga jual produk asam sunti. Kemasan yang sebelumnya hanya menggunakan kantong plastik tanpa label, saat ini 
produk asam sunti telah dijual dengan kemasan standing pouch berlabel. Setelah satu bulan pendampingan, pendapatan usaha meningkat dari $R p$ 334.000, menjadi $R p$ 436.000, dengan skala penjualan yang sebelumnya tidak terukur menjadi 80 pak ukuran 250 gr dalam satu bulan.

Cara mensitasi artikel:

Yunita, D., Nurlaila, Lubis, Y. M., \& Irfan. (2022). Pendampingan usaha rumah tangga produk lokal khas Aceh asam belimbing (Averrhoa bilimbi Linn) Sunti untuk meningkatkan mutu dan harga jualnya. Jurnal Inovasi Hasil Pengabdian Masyarakat (JIPEMAS), 5(1), 22-32. https://doi.org/10.33474/jipemas.v5i1.11514

\section{PENDAHULUAN}

Belimbing wuluh (Averrhoa bilimbi Linn) adalah buah dengan rasa asam dan tidak beraroma yang diperkirakan berasal dari Kepulauan Maluku, Indonesia dan tersebar hingga ke Sri Lanka, Myanmar, Malaysia, dan Filipina. Di Indonesia, belimbing wuluh dikenal dengan nama-nama yang berbeda yaitu belimbing botol, belimbing asam, belimbing buluh, belimbing besi, dan belimbing sayur. Buah belimbing wuluh memiliki bentuk yang lonjong, panjang $4-6,5 \mathrm{~cm}$ (Xu, et al., 2017), kandungan air yang sangat tinggi yaitu $\pm 93 \%$ serta berwarna hijau (Agustin \& Putri, 2014). Varietas lain dari belimbing wuluh memiliki warna yang berbeda yaitu kuning yang dikenal dengan nama latin Averrhoa carambola, L. (Sá, et al., 2019).

Kedua jenis belimbing ini memiliki fungsi yang sama yaitu sebagai bumbu masakan atau bahan tambahan dalam produk obat-obatan misalnya jamu. Penggunaan buah belimbing wuluh ini bisa langsung dalam keadaan segar ataupun diproses menjadi bahan baku olahan semi basah. Belimbing wuluh segar digunakan sebagai bahan campuran jamu, kosmetik, pembersih noda, penghilang bau amis, serta penghilang karat pada besi dan baja. Belimbing wuluh mengandung senyawa tanin, saponin, triterpenoid, dan flavonoid (Saputra \& Anggraini, 2016). Menurut Seebaluck-Sandoram, et al. (2019), ekstrak belimbing wuluh mampu menghambat pertumbuhan Staphylococcus aureus, V. parahaemolytius, dan E. coli. Namun, dalam keadaan buah segar dan dengan kadar air yang sangat tinggi, belimbing wuluh tidak bisa disimpan dalam waktu yang lama.

Di Provinsi Aceh, Indonesia, proses penguapan kadar air pada belimbing wuluh segar dilakukan untuk menghasilkan produk yang dikenal dengan nama asam sunti. Asam sunti digunakan sebagai salah satu bumbu masakan khas Aceh dan umumnya, asam sunti dapat disimpan dalam jangka waktu 1-1,5 tahun. Ketahanan penyimpanan produk asam sunti ini disebabkan oleh kadar air yang rendah (16\%). Kadar air asam sunti menjadi hal utama yang sangat penting untuk diperhatikan dalam proses pembuatan asam sunti. Jika asam sunti masih mengandung kadar air tinggi, maka bisa menyebabkan asam sunti membusuk dan tidak bisa disimpan dalam waktu yang lama. Kadar air yang tinggi menyebabkan tingginya aktifitas air (water activity), sehingga akan mempercepat perkembangan mikroorganisme dan mempercepat terjadinya kerusakan/pembusukan pada asam sunti.

Pembuatan asam sunti terdiri dari tiga tahap yaitu penggaraman, fermentasi, dan pengeringan. Namun, proses yang digunakan untuk mengolah belimbing wuluh segar menjadi asam sunti ini berbeda-beda, tergantung pada 
kebiasaan masyarakat setempat atau permintaan konsumen. Oleh karena itu, asam sunti yang tersedia di pasar memiliki tingkat kekeringan dan warna yang relatif berbeda. Beberapa produsen, termasuk mitra usaha PkM, mengolah asam sunti dengan cara merendam terlebih dahulu buah belimbing segar baru kemudian dijemur dan digaramkan. Produsen lainnya merebus terlebih dahulu buah belimbing segar sebelum dijemur dan digaramkan. Bahkan ada juga produsen yang langsung menjemur buah belimbing setelah panen sebelum direndam dengan air garam. Proses pembuatan asam sunti yang berbedabeda tentu saja berpengaruh kepada produk asam sunti yang dihasilkan. Lama perendaman akan memberikan efek warna coklat kehitaman pada asam sunti yang dihasilkan (Muzaifa, 2013).

Menurut Muzaifa (2018), proses pembuatan asam sunti dimulai dari pemanenan buah belimbing wuluh segar lalu dijemur hingga 2 hari dengan cuaca normal. Setelah 2 hari, warna belimbing menjadi kecoklatan dengan berat kira-kira mencapai $70 \%$ berat belimbing segar. Belimbing yang dihasilkan selanjutnya dimasukkan ke dalam baskom untuk dilumuri garam hingga rata. Belimbing yang sudah mengandung garam tersebut dimasukkan ke dalam kantong plastik. Kantong plastik tersebut diikat dengan tali agar kedap udara dan didiamkan selama satu malam supaya terjadi fermentasi spontan. Keesokan harinya, belimbing tersebut dijemur kembali selama 8-9 jam di terik matahari dan dilakukan penggaraman tahap kedua. Hal ini dilakukan hingga penggaraman tahap ketiga. Belimbing tersebut dijemur hingga dua hari berturut-turut bisa dibantu dengan pengadukan agar dapat mempercepat proses penguapan air hingga didapatkan berat produk asam sunti sebanyak $16 \%$ dari berat belimbing wuluh awal.

Produk asam sunti dijual dengan harga dan cara kemas yang beragam. Umumnya, asam sunti dijual dalam bentuk kiloan dengan bungkus plastik dan dengan tampilan fisik produk yang kurang baik seperti yang dilakukan oleh usaha rumah tangga di Desa Alue Jeureujak, Kecamatan, Babahrot, Kabupaten Aceh Barat Daya, Provinsi Aceh. Asam sunti yang dihasilkan memiliki warna gelap kehitaman, sangat keriput, dan sangat banyak mengandung bendabenda asing yang tidak diinginkan seperti potongan tangkai belimbing, kelopak bunga, daun belimbing, serangga, dan berbagai benda lainnya. Selain itu, penggunaan plastik sebagai pembungkus juga dapat mempengaruhi kualitas produk. Oleh karena itu, pada kegiatan pengabdian kepada masyarakat (PkM) ini, perbaikan proses dan kemasan produk asam sunti dilakukan agar mutu produk yang dihasilkan menjadi lebih baik dan harga jual dapat ditingkatkan.

\section{METODE PELAKSANAAN}

Pelaksanaan kegiatan PkM berlangsung sejak bulan Juni 2020 hingga Agustus 2020 dengan pendampingan langsung di lokasi selama 1 bulan. Kegiatan PkM dilaksanakan di satu usaha rumah tangga asam sunti yang dimiliki oleh Ibu Raimah yang terletak di Desa Alue Jeureujak, Kecamatan, Babahrot, Kabupaten Aceh Barat Daya, Provinsi Aceh. Adapun pelaksanaan kegiatan dimulai dengan persiapan, lalu dilanjutkan dengan kegiatan utama (pendampingan) dan evaluasi hasil. 
Pada tahap persiapan, peninjauan rumah dan proses produksi serta penyusunan jadwal pendampingan dilakukan dengan komunikasi langsung bersama pemilik usaha. Tim pengabdi mengumpulkan informasi terkait proses produksi untuk kemudian dijadikan sebagai dasar perbaikan proses yang dilakukan. Pada saat pendampingan, kegiatan yang dilakukan adalah perbaikan proses pembuatan asam sunti, perbaikan kemasan produk asam sunti, dan perhitungan harga jual produk asam sunti. Selanjutnya, pada tahap evaluasi hasil, keberhasilan kegiatan dilihat dari peningkatan mutu asam sunti menjadi Mutu I (Tabel 1) dan jumlah pendapatan dan laba setelah kegiatan pendampingan selama satu bulan.

Tabel 1. Tingkatan mutu asam sunti (Hayati et al., 2002)

\begin{tabular}{|c|c|c|c|c|}
\hline $\begin{array}{c}\text { Tingkatan } \\
\text { Mutu }\end{array}$ & Warna & $\begin{array}{c}\text { Penampakan } \\
\text { Permukaan }\end{array}$ & Kekerasan & $\begin{array}{c}\text { Kotoran } \\
\text { (Sisa Tangkai) }\end{array}$ \\
\hline $\mathrm{I}$ & Coklat Muda & Tidak Berkeriput /licin & Lunak & Tidak ada \\
\hline II & $\begin{array}{l}\text { Coklat muda - } \\
\text { coklat tua }\end{array}$ & $\begin{array}{c}\text { Tidak berkeriput-sedikit } \\
\text { berkeriput }\end{array}$ & $\begin{array}{l}\text { Lunak-agak } \\
\text { licin }\end{array}$ & sedikit \\
\hline III & $\begin{array}{c}\text { Coklat tua } \\
\text { kehitam-hitaman }\end{array}$ & Sangat berkeriput & $\begin{array}{c}\text { Agak liat-liat } \\
\text { dan sangat liat }\end{array}$ & banyak \\
\hline
\end{tabular}

Adapun perbaikan proses pembuatan asam sunti yang diterapkan pada objek PkM adalah sebagai berikut:

\section{Pemanenan Buah Belimbing Wuluh}

Buah yang dipanen memiliki tingkat kematangan yang seragam. Tanda buah belimbing sudah bisa dipanen adalah memiliki warna hijau pekat atau hijau kekuningan, tekstur buah yang keras menuju lunak, kondisi kulit buah yang licin, dan tampak membengkak. Proses pemanenan dilakukan dengan menggunakan galah dengan kain saring pada bagian ujung untuk menghindari buah langsung jatuh ke tanah.

\section{Pencucian}

Pencucian dilakukan dalam keranjang besar dengan kondisi buah belimbing tetap dalam keranjang, buah belimbing tersebut digosok-gosok agar tidak ada kotoran yang menempel. Kemudian kotoran yang mengapung dipisahkan dari buah belimbing. Pencucian dilakukan sebanyak 3 kali hingga belimbing terlihat bersih dari kotoran yang menempel saat pemanenan. Setelah pencucian, buah belimbing disiram dengan air mengalir sambil dipindahkan ke dalam baskom besar.

\section{Perendaman}

Setelah buah belimbing dicuci bersih, buah belimbing direndam dengan air bersih. Tahapan ini berguna untuk membuat buah belimbing lebih layu sehingga akan mempercepat proses pengeringan. Pada proses ini, fermentasi awal oleh bakteri yang terkandung pada buah dapat berlangsung. Proses perendaman dilakukan selama dua malam dengan keadaan baskom ditutup rapat dengan penutup baskom atau dengan kantong plastik yang diikat melingkar pada baskom.

\section{Penjemuran}

Proses penjemuran bertujuan untuk mengurangi kadar air pada buah belimbing. Buah belimbing yang sudah layu akan lebih cepat mengalami 
proses penguapan air. Penjemuran awal biasanya membutuhkan waktu 78 jam setiap harinya selama 2-3 hari pada keadaan cuaca yang normal. Lama penjemuran mencapai 7-8 jam setiap harinya dan diaduk setiap 3-4 jam selama 5-6 hari. Pada saat penjemuran, pengecekan kondisi fisik buah dilakukan untuk memastikan tidak ada sisa tangkai pada buah. Proses kritis dalam pembuatan asam sunti adalah pada tahapan penjemuran (pengeringan) dan fermentasi (Putri et al., 2015).

5. Penggaraman (Fermentasi spontan)

Pada penggaraman tahap pertama, buah belimbing yang telah dijemur, dilumuri garam dengan cara memasukkan buah belimbing sedikit demi sedikit ke dalam baskom lalu kemudian ditaburi garam hingga semua belimbing tercampur rata dengan garam. Jumlah garam yang digunakan yaitu 1:2 (1 bungkus garam ( $250 \mathrm{~g}$ ) untuk $2 \mathrm{~kg}$ belimbing). Buah belimbing yang sudah dilumuri dengan garam dimasukkan ke dalam baskom besar yang tertutup rapat dengan penutup baskomnya dan didiamkan selama satu malam.

Pada penggaraman tahap kedua, buah belimbing dijemur kembali selama 1 hari. Penggaraman tahap kedua dilakukan seperti penggaraman tahap pertama dan didiamkan selama satu malam dalam kondisi wadah yang tertutup rapat. Hal yang sama dilakukan pada penggaraman tahap ketiga. Penggaraman tahap ketiga adalah penggaraman terakhir dengan kondisi penjemuran yang normal. Namun, pada musim hujan penambahan tahapan penggaraman menjadi dibutuhkan. Setelah proses penggaraman terakhir, buah belimbing didiamkan dengan kondisi wadah tertutup selama satu malam. Selanjutnya, buah belimbing dijemur selama 2-3 hari hingga berat $16 \%$ dari belimbing wuluh awal.

\section{HASIL DAN PEMBAHASAN}

\section{Persiapan Pelaksanaan PkM}

Kunjungan ke mitra usaha mendapat sambutan yang sangat baik. Tahap kunjungan ini menyepakati bahwa kegiatan pendampingan dilakukan setiap hari selama 1 bulan. Selain itu, mitra usaha juga bersedia dibina untuk melakukan seluruh perbaikan yang disarankan oleh tim pengabdi.

Hasil pengamatan tentang proses pembuatan asam sunti pada mitra usaha rumah tangga ini yaitu hanya terdiri dari proses perendaman belimbing wuluh yang diikuti oleh tahap penjemuran. Penjualan asam sunti juga dilakukan dengan kantung plastik. Penampakan permukaan asam sunti sebelum kegiatan PkM dapat dilihat pada Gambar 1. Sedangkan kemasan yang digunakan dapat dilihat pada Gambar 2. 


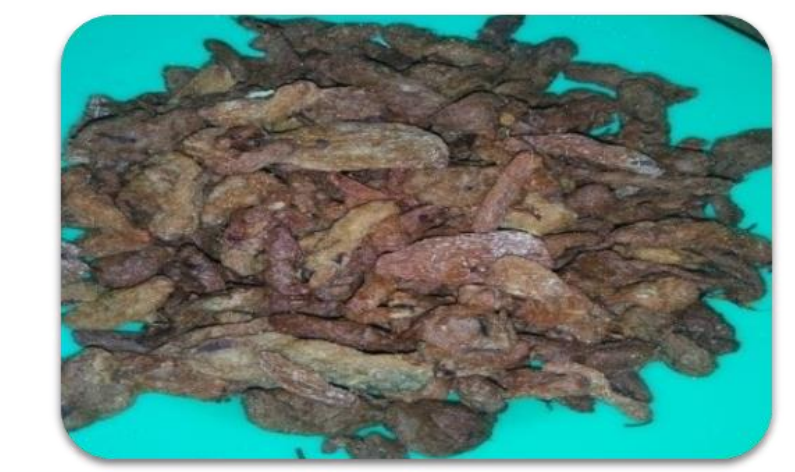

Gambar 1. Penampakan produk asam sunti sebelum kegiatan PkM

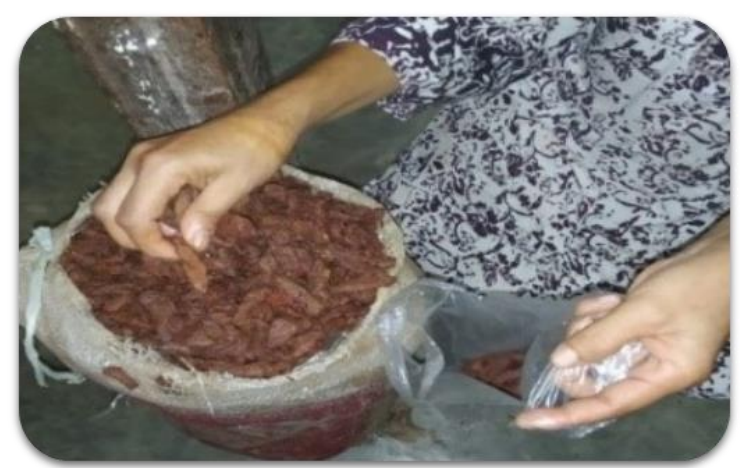

Gambar 2. Produk asam sunti sebelum kegiatan PkM yang dikemas dengan kantong plastik

\section{Perbaikan Proses Pembuatan Asam Sunti}

Asam sunti merupakan bumbu masakan khas Aceh yang dihasilkan dari pengeringan, penggaraman dan fermentasi belimbing wuluh. Warna asam sunti pada umumnya adalah coklat dengan bentuk yang datar (Mulyati, et al., 2019). Pada saat pendampingan, perbaikan proses pembuatan asam sunti mengikuti prosedur yang tertera pada bagian metode. Asam sunti juga dirapikan pada tahap perbaikan fisik sehingga memiliki bentuk yang jauh lebih bagus dibandingkan dengan asam sunti yang tidak dirapikan (Gambar 3). Cara pengerjaannya adalah dengan mengambil satu per satu asam sunti dan rapikan dengan tangan. Pada saat ini pula dilakukan pembersihan asam sunti dari kotoran atau benda lain yang menempel pada asam sunti secara manual menggunakan tangan. Selain itu, proses penjemuran dengan waktu yang tidak cukup dan panas yang tidak sesuai akan berdampak pada warna asam sunti menjadi kehitaman. Jika dibandingkan dengan tingkatan mutu asam sunti seperti yang tertera pada Tabel 1, tingkatan mutu produk asam sunti Ibu Raimah sebelum kegiatan PkM dilaksanakan berada pada tingkat III. Setelah pendampingan, tingkatan mutu produk asam sunti menjadi tingkat I. 


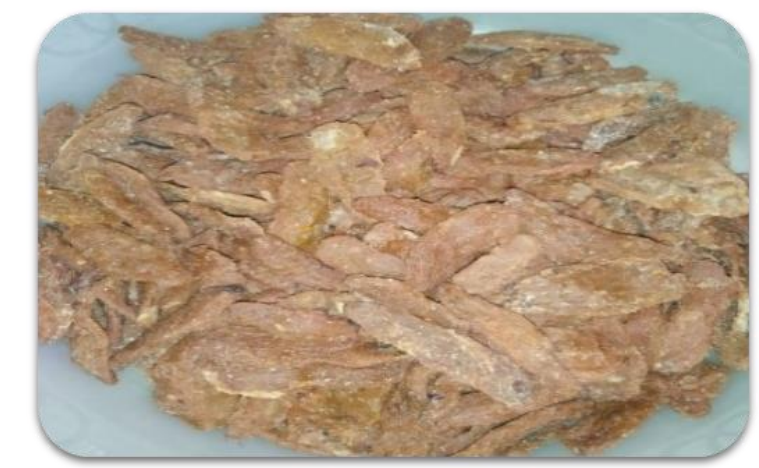

Gambar 3. Penampakan produk asam sunti setelah kegiatan PkM

Kemasan asam sunti yang digunakan berbentuk standing pouch packaging (SPP) yang terbuat dari polypropylene. Menurut Wijayanti, et al. (2016), kemasan dengan bahan tersebut menunjukkan kemampuan menghalang kelembaban dengan baik. Ukuran kemasan yang digunakan adalah kemasan untuk berat bahan 250 gram (2,5 ons). Stiker/label kemasan didesain dan ditempel pada bagian depan SPP sehingga konsumen dapat langsung melihat kondisi asam sunti yang dijual. Stiker juga berisi beberapa informasi seperti nama produk, berat produk, gambar asam sunti, dan asal tempat produksi. Desain stiker yang diberikan dapat dilihat pada Gambar 4. Stiker kemasan lebih terlihat menarik dengan perpaduan warna orange, putih, dan hijau muda dengan gambar belimbing segar yang berkesan abstrak. Stiker yang didesain dapat diubah seperlunya seiring dengan penambahan informasi apapun terkait asam sunti seperti nomor P-IRT, BPOM, halal MUI, dan informasi lainnya.

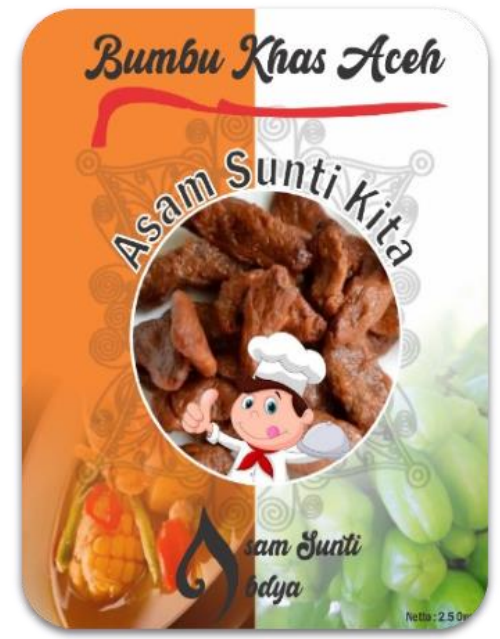

Gambar 4. Desain kemasan produk asam sunti hasil pendampingan 


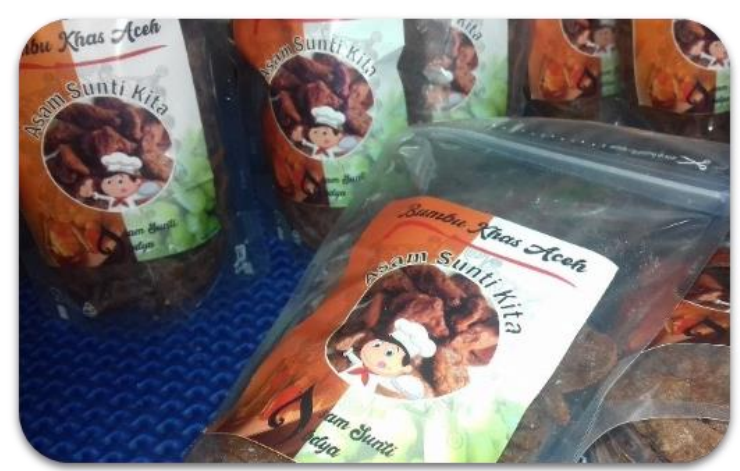

Gambar 5. Produk asam sunti dalam kemasan standing pouch packaging (SPP) berlabel

Kualitas produk tidak hanya dipengaruhi oleh bentuk fisik dari produk yang dihasilkan, melainkan juga tampilan luar produk atau kemasan produk. Kemasan yang layak dan bagus akan meningkatkan nilai dari suatu produk. Produk dengan kemasan yang bagus akan mudah mencapai pasar yang lebih luas. Untuk produk lokal yang sudah dikemas dengan bagus bisa dijadikan oleh-oleh khas daerah penghasilnya (Mubarrok et al., 2021). Terkhusus untuk produk asam sunti yang sifat fisiknya lunak dan mudah rusak jika ditekan atau diletakkan berhimpit dengan benda berat lainnya. Produk jenis ini tentu saja membutuhkan kemasan yang aman agar dapat menjamin keutuhan produk. Oleh karena itu, pengemasan merupakan salah satu titik utama yang perlu dikembangkan dalam usaha asam sunti ini agar menjadi produk yang bernilai jual tinggi dan dapat bersaing dengan produk lainnya di pasar.

\section{Perhitungan Harga Jual Asam Sunti}

Harga asam sunti yang dijual oleh lbu Raimah sebelum pendampingan adalah $\mathrm{Rp} 20.000$ per $\mathrm{Kg}$. Harga tersebut dihitung tanpa ada perhitungan modal ataupun gaji pekerja. Ibu Raimah merasa harga tersebut sudah sangat sesuai dengan keadaan pasar di daerahnya. Hal ini juga dikarenakan bahan baku didapatkan langsung dari kebun pribadi serta semua proses pengolahan tidak menggunakan tenaga kerja luar. Semua proses pengolahan dilakukan oleh keluarga Ibu Raimah. Perhitungan biaya produksi, harga jual, pendapatan dan laba usaha pada satu bulan sebagai berikut:

\section{a. Biaya Bahan}

Plastik = Rp 6.000/ pack

Garam $=$ Rp 1.000/bungkus ( 3 bungkus $/ \mathrm{kg}$ )

Kebutuhan garam $/$ bulan $=3.000 \times 20=$ Rp. 60.000

Total biaya bahan / Kg = Rp 66.000

b. Harga Jual, Pendapatan, dan Laba

Harga jual = Rp. $20.000 / \mathrm{Kg}$

Jumlah asam sunti terjual $=20 \mathrm{Kg} /$ Bulan 


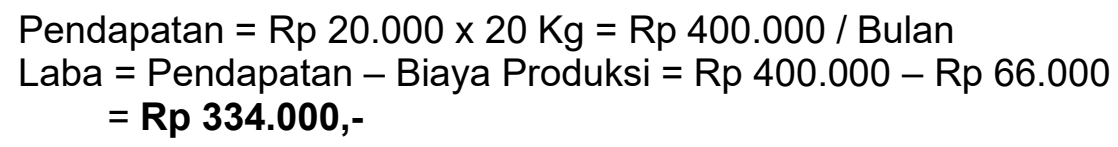

Adanya perbaikan proses dari produksi asam sunti merubah perhitungan keuangan usaha asam sunti. Perubahan perhitungan keuangan tersebut didasari oleh adanya beberapa penambahan bahan dan proses produksi. Dengan adanya perbaikan secara fisik produk, harga jual asam sunti tersebut akan meningkat. Perhitungan biaya produksi, harga jual dan pendapatan usaha pada satu bulan pertama pasca kegiatan PkM dengan jumlah produk terjual 80 kemasan $250 \mathrm{gr}(20 \mathrm{~kg})$ adalah sebagai berikut:

\section{a. Biaya Bahan}

Kemasan SPP ukuran $250 \mathrm{gr}=$ Rp. $200 /$ lembar

Stiker kemasan $=$ Rp. $600 /$ lembar

Garam $=\operatorname{Rp} 1.000 /$ bungkus $(3$ bungkus $/ \mathrm{kg})=20 \mathrm{~kg} \times 3000=R p$. 60.000

(dibutuhkan Rp. 750/kemasan $250 \mathrm{~g}$ )

Total biaya bahan/ kemasan $250 \mathrm{gr}=\mathrm{Rp}(200+600+750)=\mathrm{Rp} .1 .550$

Total biaya bahan $/ 80$ kemasan $250 \mathrm{gr}=\operatorname{Rp} 1.550 \times 80=\operatorname{Rp} 124.000$

b. Harga Jual, Pendapatan, dan Laba

Harga jual produk $=$ Rp $7.000 /$ Kemasan $250 \mathrm{gr}$

Pendapatan $=R p 7.000 \times 80$ kemasan $=R p 560.000 /$ bulan

Laba $=$ Pendapatan - Biaya Produksi $=\operatorname{Rp} 560.000-$ Rp 124.000

$=\operatorname{Rp} 436.000,-$

\section{Evaluasi Hasil}

Perbaikan proses (penjemuran dan pengemasan) dapat meningkatkan pendapatan dari Rp 334.000,- menjadi Rp 436.000,-. Perbaikan kemasan asam sunti memudahkan Ibu Raimah menjual asam sunti ke pasar yang lebih luas. Pemasaran yang lebih luas membuat produksi asam sunti Ibu Raimah juga menjadi semakin meningkat sehingga semakin meningkat pula pendapatan dari usaha asam sunti tersebut. Jika usaha terus berkembang, pembelian kemasan SPP dan cetak stiker dapat dilakukan dalam jumlah besar untuk mengurangi biaya bahan.

\section{KESIMPULAN}

Usaha rumah tangga asam sunti lbu Raimah merupakan salah satu usaha di Kecamatan Babahrot, Kabupaten Aceh Barat Daya, Provinsi Aceh yang perlu ditingkatkan produksinya; tidak hanya untuk memperbaiki kualitas produk yang dihasilkan, tetapi juga untuk meningkatkan pendapatan. Titik kritis dari proses pembuatan asam sunti adalah pada tahap penjemuran dan penggaraman. Kedua proses tersebut sangat berpengaruh terhadap kadar air dari asam sunti sehingga sangat menentukan kualitas fisik dan lama penyimpanan dari asam sunti yang dihasilkan. Selain produk, proses 
pengemasan yang baik juga dibutuhkan untuk menjaga kualitas produk yang dihasilkan. Kedua hasil akhir yang diinginkan (perbaikan produk akhir dan peningkatan pendapatan) telah tercapai setelah kegiatan PkM.

\section{UCAPAN TERIMA KASIH}

Penulis mengucapkan terima kasih setinggi-tingginya kepada Ibu Raimah yang merupakan salah satu pemilik usaha rumah tangga asam sunti di Desa Alue Jeureujak, Kecamatan, Babahrot, Kabupaten Aceh Barat Daya, Provinsi Aceh yang telah bersedia menjadi subjek kegiatan PkM.

\section{DAFTAR RUJUKAN}

Agustin, F., \& Putri, W. D. R. (2014). Pembuatan Jelly Drink Averrhoa blimbi L. (Kajian Proporsi Belimbing Wuluh: Air dan Konsentrasi Karagenan). Jurnal Pangan dan Agroindustri, 2(3), 1-9. https://jpa.ub.ac.id/index.php/jpa/article/view/46

Hayati, R., Soewarno, Soekarto, T., \& Nuraida, L. (2002). Kajian Penggaraman dan Pengeringan Belimbing Wuluh (Averrhoa bilimbi L.) dalam Pembuatan Asam Sunti dari Aceh. Agripet, 3(1), 29-36. https://doi.org/10.17969/agripet.v3i1.3820

Mubarrok, U. S., Fajariah, N., \& Yani, A. (2021). Fasilitasi Peningkatan Kompetensi Wirausaha Kuliner di Era Pandemi. Jurnal Inovasi Hasil Pengabdian Masyarakat (JIPEMAS), 4(2), 190-198. https://doi.org/10.33474/jipemas.v4i2.9249

Mulyati, S., Pramesthy, F. A., Meutia, F., Rinaldi, A., Siregar, S. M., \& Muchtar, S. (2019). Effects of Temperature and Duration of Drying on the Quality of Powdered Asam Sunti. IOP Conference Series: Materials Science and Engineering, 523, $012025 . \quad$ https://doi.org/10.1088/1757899X/523/1/012025

Muzaifa, M. (2013). Perubahan Karakteristik Fisik Belimbing Wuluh selama Fermentasi Asam Sunti. Jurnal Teknologi \& Industri Pertanian Indonesia, 5(2), 7-11. https://doi.org/10.17969/jtipi.v5i2.1002

Muzaifa, M. (2018). Perubahan Komponen Kimia Belimbing Wuluh (Averrhoa bilimbi L.) selama Pembuatan Asam Sunti. Jurnal Teknologi Pertanian Andalas, 22(1), 37-43. https://doi.org/10.25077/jtpa.22.1.37-43.2018

Putri, F., Indah, H., \& Utama, G. L. (2015). Preliminary Identification of Potential Halophilic Bacteria Isolated from 'Asam Sunti' - Indonesian Traditional Herbs, in Inhibiting the Growth of E. coli and Salmonella spp. International Journal on Advanced Science, Engineering and Information Technology, 5(3), 152-154. https://doi.org/10.18517/ijaseit.5.3.509

Sá, R. D., Vasconcelos, A. L., Santos, A. V., Padilha, R. J. R., Alves, L. C., Soares, L. A. L., \& Randau, K. P. (2019). Anatomy, Histochemistry and Oxalic Acid Content of the Leaflets of Averrhoa bilimbi and Averrhoa carambola. Revista Brasileira de Farmacognosia, 29(1), 11-16. https://doi.org/10.1016/J.BJP.2018.09.005

Saputra, O., \& Anggraini, N. (2016). Khasiat Belimbing Wuluh (Averrhoa bilimbi L.) terhadap Penyembuhan Acne Vulgaris. Majority, 5(1), 76-80. 
Seebaluck-Sandoram, R., Lall, N., Fibrich, B., Blom van Staden, A., Saleem, H., \& Mahomoodally, M. F. (2019). Antimicrobial, Antioxidant and Cytotoxic Evaluation of Two Underutilised Food Plants: Averrhoa bilimbi L. (Oxalidaceae) and Phyllanthus acidus L. Skeels (Phyllanthaceae). Biocatalysis and Agricultural Biotechnology, 18, 100998. https://doi.org/10.1016/J.BCAB.2019.01.036

Wijayanti, I., Surti, T., Anggo, A. D., \& Susanto, E. (2016). Effect Different Packaging on Proximate and Lysine Content of Milkfish [Chanos Chanos (Forsskål, 1775)] Floss During Storage. Aquatic Procedia, 7, 118-124. https://doi.org/10.1016/j.aqpro.2016.07.016

Xu, E., Wijaya, C. H., \& Faridah, D. N. (2017). Characterization of Aroma Compounds in Indonesian Traditional Seasoning (Asam Sunti) made from Averrhoa bilimbi L. Emirates Journal of Food and Agriculture, 29(5), 378386. https://doi.org/10.9755/ejfa.2016-11-1577 